Psihologijske teme, 30 (2021), 3, 573-590

Izvorni znanstveni rad

UDK: 519.237 .7

https://doi.org/10.31820/pt.30.3.9

159.9.075(866)

\title{
Psychometric Properties of the General Health Questionnaire (GHQ-28) in Ecuadorian College Students
}

\author{
Rodrigo Moreta-Herrera ${ }^{1,2}$, Sergio Dominguez-Lara ${ }^{3}$, Diego Vaca-Quintana ${ }^{4}$, \\ Joselyn Zambrano-Estrella ${ }^{5}$, Daniel Gavilanes-Gómez ${ }^{5}$, \\ Erika Ruperti-Lucero ${ }^{6}$, and Daniela Bonilla ${ }^{4}$ \\ ${ }^{1}$ Pontificia Universidad Católica del Ecuador, Quilto, Ecuador \\ ${ }^{2}$ Universidad Autónoma de Madrid, Madrid, Spain \\ ${ }^{3}$ Universidad Privada San Juan Bautista, Lima, Perú \\ ${ }^{4}$ Universidad Tecnológica Indoamérica, Quilto, Ecuador \\ ${ }^{5}$ Universidad Técnica de Ambato, Ambato, Ecuador \\ ${ }^{6}$ Universidad Estatal de Milagro, Milagro, Ecuador
}

\begin{abstract}
Objective: To analyse the internal structure of the 28-item version of the General Health Questionnaire (GHQ-28), as well as its reliability and validity in relation to other variables in a sample of Ecuadorian university students. Method: Instrumental design with confirmatory factor analysis using weighted least square mean and variance adjusted (WLSMV) estimator, reliability and convergence and discrimination validity of the GHQ-28. Sample: 495 students (56.6\% women), between 18 to 35 years old ( $M=24.1$ years; $S D=2.1)$, from three universities $(59.6 \%$ public) in Ecuador. Results: The bifactor model of the GHQ-28 test has an adequate fit with $\chi^{2}=357.81$; $p>.05 ; d f=322 ; \chi^{2} / d f=1.11 ; \mathrm{CFI}=.991 ; \mathrm{TLI}=.989 ; \mathrm{SRMR}=.059 ; \mathrm{RMSEA}=.015$ [.000 - .023]; $\omega_{\mathrm{H}}=.93 ; \mathrm{ECV}=.90 ; \mathrm{PUC}=.78$. The GHQ-28 is reliable and in terms of convergent validity, it correlates significantly and negatively with mental health, assessed by MHC-SF, and it is discriminant between risk and non-risk cases. Conclusion: The GHQ-28 bifactor model is replicable in Ecuadorian college students.
\end{abstract}

Keywords: bifactor model, factor analysis, mental health, reliability, validation

\section{Introduction}

Health is a state of complete biological, psychological, and social well-being of individuals, and not only the absence of disease (World Health Organization [WHO], 1946). Thus, mental health is a key component for the development of well-being

Rodrigo Moreta-Herrera, School of Psychology of Pontificia Universidad Católica del Ecuador Sede Ambato, Manuela Sáenz, Av. And Remigio Crespo street, Ambato Ecuador. P.O. 180103. Email: rmoreta@ pucesa.edu.ec 
and balance in the remaining spheres (Vera-Villarroel et al., 2016; WHO, 2001). In addition, it is related to the subjective assessment of one's own state in general (introspection), coping with stress, productivity and, contribution to the community (WHO, 2014), therefore, without mental health there is no true health in general (Prince et al., 2007; Moreta-Herrera et al., 2018).

Mental health care is important for an optimal lifestyle, although it is generally underestimated (Walsh, 2011). It is also an important factor in the outcomes of educational processes (Cornaglia et al., 2015). In this respect, school populations (including university ones) are vulnerable in terms of balanced mental health. University students, although expected to be healthy, are not completely healthy (Khodarahimi \& Fathi, 2016) and they are at risk for mental problems (Hope \& Henderson, 2014; Saleh et al., 2017; Tran et al., 2017), performance difficulties, social adaptation challenges (Berlin et al., 2012; Lipson et al., 2015), productivity issues (Mayorga-Lascano \& Moreta-Herrera, 2019) and others. Therefore, constant monitoring of these groups is important for good control and care of their health.

As in other populations, a difficulty at mental health monitoring in college students is the lack of adequate assessment tools (Prady et al., 2013; Moreta-Herrera, Perdomo-Pérez et al., 2021). Although there are self-report tests, many lose reliability and validity due to an excessive precision bias or measurements not properly calibrated and standardized. For example, some repeated problems are the absence of monitoring of the structural configuration of a measure over time and the lack of adaptation to the characteristics (culture, language, age group, others) of the population. This is the case of the Ecuadorian population, where research on mental health is scarce (Contreras et al., 2017; Moreta-Herrera, Zambrano-Estrella et al., 2021) and on assessment tools such as the General Health Questionnaire (GHQ, Goldberg, 1978) which, although widely used, does not count with extensive research on its psychometric properties both in Ecuador and in Latin American region.

\section{The General Health Questionnaire and the Question of its Measure}

The General Health Questionnaire (GHQ) is an instrument frequently used worldwide to assess the perception of health and the risk of psychopathology in primary health care (Goldberg, 1978). It has different versions (12, 17, 28, and 60 items) and translations in more than 38 languages (Sterling, 2011), Spanish included (Lobo et al., 1986). The 28-item version (GHQ-28) is the most well-known and popular version of the GHQ, which possess four factors: a) Somatic symptoms (items 1 to 7); b) Anxiety/insomnia (items 8 to 14); c) Social dysfunction (items 15 to 21) and d) Severe depression (items 22 to 28) (Goldberg \& Hillier, 1979), and it is rated based on a four-option scale. The evaluation mechanism varies in terms of the identification of discomfort conditions, whether recent or chronic, according to evaluation needs. 
Moreta-Herrera, R., Dominguez-Lara, S., Vaca-Quintana, D., Zambrano-Estrella, J., Gavilanes-Gómez, D., Ruperti-Lucero, E., Bonilla, D.: Validation and Reliability of GHQ-28 in Ecuador

Although studies that analyse the structure of four factors of the GHQ-28 stand out, most of them only use exploratory factor analysis (EFA) (Galindo et al., 2017; Lobo et al., 1986; Vallejo et al., 2014). Even when this technique is acceptable for a test validation process, according to Classical Test Theory (CTT), it is not enough (Batista-Fogueta et al., 2004) since it does not provide enough evidence to validate the construct. Therefore, confirmatory factor analysis (CFA) through structural equations model (SEM), is required to obtain more precise data of the factorial validity of a test (Ferrando \& Anguiano-Carrasco, 2010).

CFA as a technique in the analysis of GHQ-28 is unusual and rarely used in recent scientific literature. Certain studies stand out, and most of them confirm the four-dimensional model in clinical samples such as in Spain (Pérez et al., 2010), South Africa (de Kock et al., 2014), Iran (Ghanbarnejad et al., 2013) and in a general Norwegian sample without an adequate adjustment (Hjelle et al., 2019). There is also a study on a 17 items version (items 5, 6, 7, 8, 9, 14, 20, 21, 22, 27, 28 eliminated) carried out in a multi-ethnic population residing in England (British, Pakistani, Urdu, others) with indicators of good fit (Prady et al., 2013). However, studies within college samples are difficult to find, and in the case of Latin America and Ecuador, they are non-existent, despite the widespread use of the GHQ-28 for empirical research (Garrido \& Delgado, 2017; Zapata \& Giraldo, 2012).

To date, current reports do not provide enough evidence about the adequacy of the factor structure of the GHQ-28 using SEM. It is also uncertain whether or not the four-dimensional configuration for this test is ideal. Likewise, former studies are limited in terms of specifying procedures regarding preliminary criteria such as multivariate normality, the configuration of the scale of measurement of the items and, the estimators for CFA, elements that are usually part of the current scientific debate around instrumental validation ( $\mathrm{Li}, 2016)$. Although it is usual to obtain a global score through the sum of all the items, current psychometric evidence does not support the existence of a latent general factor that groups all the items of the GHQ-28, and this could generate problems in the interpretive capacity of the measure. It should be considered that the specific factors evaluate different psychological symptoms (somatization, anxiety-insomnia, social dysfunction, and depression), so it is necessary to analyse whether the GHQ-28 has a bifactorial structure behind it (Chen et al., 2006; Holzinger, 1937). That is, to check the existence of a general factor (GF) that accounts for the similarity between the factors of the scale; and on the other hand, of multiple specific factors (SF) that explain their particular influence over the general factor (Chen et al., 2013). A bifactor solution of GHQ-28, which has not previously been explored in the scientific literature, could enhance the versatility of the test for both research and diagnosis.

Regarding the exploration of other psychometric properties of the GHQ-28, unlike factorial validity, there is solid evidence about the reliability of the instrument in different samples around the world and within college students (de Kock et al., 2014; Galindo et al., 2017; Ghanbarnejad et al., 2013; Hjelle, Bragstad, Zucknick et 
al., 2019; Lobo et al., 1986; Pérez et al., 2010; Vallejo et al., 2014). However, as proposed by Batista-Fogueta et al. (2004), reliability is a property that must be explored after verifying factorial validity; in consequence, many of these studies could be discarded. Within convergence validity, the GHQ-28 positively converges with tests that assess the perception of health such as the SF-36 in low and moderate ranges (Failde et al., 2000) and also with assessment tools of anxiety and depression (Chen et al., 2010).

The presence of gaps in empirical and methodological studies regarding the performance of the GHQ-28 is evident. Instrumental exploration of the GHQ-28 requires more validation methods (especially CFA through SEM) since previous methods applied in the scientific literature are not enough to confirm the adequate adjustment of the four dimensions model or even of new configurations in Latin American and Ecuadorian university populations. Therefore, research about the psychometric properties of this assessment tool will contribute to enhancing the knowledge around the validity of the GSQ-28, especially around the invariability of the proposed model when confronted with cultural and linguistic particularities of assessed populations, giving greater confidence to the test for future evaluations and diagnoses.

\section{Objectives and Hypotheses}

The objectives of the study are a) to confirm the best model fit (four factors and bifactor) of the GHQ in its 17 and 28 items versions, in a sample of Ecuadorian college students. As H1, it is estimated that the bifactor model with 28 items has an adequate fit; $b$ ) to identify the reliability of the GHQ. As H2, reliability is considered to be acceptable and greater than .80 ; c) to ratify convergence validity of the GHQ28 by means of the MHC-SF test. As H3 it is assumed that the test has moderate convergence validity $(r>.60)$.

\section{Methodology}

\section{Participants}

The sample corresponded to 495 students; $56.6 \%$ are women, between 18 and 35 years, with a mean age of $M=24.1(S D=2.1)$; $90.1 \%$ define themselves as mestizos (Aboriginal descendants with Europeans or Asians), while 9.9\% are indigenous and Afro-Ecuadorian. Regarding place of residence, $85.9 \%$ come from urban sectors and $14.1 \%$ from rural areas; and $19 \%$ of the participants present a socio-economic risk due to difficulties in their families. Students are currently attending 13 different undergraduate careers at three universities (59.6\% public) of Tungurahua and Cotopaxi in Ecuador; $12.3 \%$ present academic risk due to low performance, while $13.5 \%$ pay their studies through financial aids and scholarships. 
Moreta-Herrera, R., Dominguez-Lara, S., Vaca-Quintana, D., Zambrano-Estrella, J., Gavilanes-Gómez, D., Ruperti-Lucero, E., Bonilla, D.: Validation and Reliability of GHQ-28 in Ecuador

Selection of the participants was carried throughout a non-probability convenience sampling with the following inclusion criteria: a) Students above legal age; b) Legally registered and with regular attendance; c) Voluntary participation; d) Proper physical and mental state to carry out the evaluation and e) Written and signed consent to participate in the study.

\section{Instruments}

28-item General Health Questionnaire (GHQ-28, Goldberg, 1978) in its Spanish version by Lobo et al. (1986). This instrument assesses the general perception of health, based upon 28 items on a four-option scale. The responses are analysed based on four subscales: a) Somatization, b) Anxiety-insomnia, c) Social difficulties and d) Depression. There are several methods to score the GHQ-28, one of these is the binary method, which assigns 0 points for the answer options "Not at all" and "No more than usual"; and one point for the answer options "Rather more than usual" and "Much more than usual". Using this method, a total score greater than 4 indicates the presence of a psychiatric case. In the current scientific literature, reliability of Cronbach's $\alpha=.94$ (Vergara-Moragues \& González-Saiz, 2020) and $\alpha$ $=.95$ (Gibbons et al., 2004) has been reported.

Mental Health Continuum-Short Form (MHC-SF, Keyes, 2005) in its Spanish version of Echeverría et al. (2017). Designed to assess the positive perception of mental health in a 14 items questionnaire completed on a five-options Likert scale, where 1 is never and 5 is always. The MHC-SF has three subscales that assess emotional, psychological and social well-being. It is a scale of regular use in academic research, with several translations and adaptations in different countries and languages such as Polish, Arabic, Armenian, Russian, Flemish, French, Portuguese, Bulgarian and others (Karaś et al., 2014; Żemojtel-Piotrowska et al., 2018) with an adequate fit of a three dimensions model. Recently there is an adaptation to the Ecuadorian population, with an adequate adjustment and reliability of McDonald's $\omega=.93$ equivalent to high (Contreras et al., 2017). Since it measures the perception of mental health, it will be used to analyse convergence validity in this study.

\section{Procedure}

After the authorization of the educational centres, voluntary participation of the students was requested to be part of the project. First, interested students received information about the objectives, the form of participation, and the treatment that will be given to the information provided by them and then they signed the respective letters of consent in order to participate in the study. Participants completed the questions of each test in their classrooms under the supervision of the research project staff. Once the evaluation was completed, data were refined and only those evaluations with complete information were considered. It should be noted that this 
report is part of the research project called: "The current state of mental health of college students in Cotopaxi and Tungurahua" which was reviewed and approved by the Psychology faculty of the Pontificia Universidad Católica del Ecuador Sede Ambato and it followed the guidelines suggested by the Helsinki convention on ethical care for research.

\section{Data Analysis}

This study applied an instrumental design (Ato et al., 2013) to confirm the adjustment of the bifactor structure of the GHQ-28 (Goldberg, 1978) in a sample of Ecuadorian college students, as well as its reliability and convergence and discriminant validity.

Statistical treatment of data is divided into three blocks. The first block corresponds to a preliminary analysis of the items, including mean $(M)$, standard deviation $(S D)$, skewness $(g 1)$, and kurtosis $(g 2)$. In addition, univariate normality assumption is verified when the values of $g 1$ and $g 2$ are within the parameter \pm 2 (Field, 2009). Also, multivariate normality was checked, which is fulfilled when values of skewness and kurtosis are not statistically significant $(p>.05)$ in the Mardia test (1970).

The second block comprises the CFA of the GHQ-28 to know the fit presented by the four-dimensional and 28-item model. WLSMV estimator is used through a matrix of polychoric correlations. This is the most suitable method for categorical variables without multivariate normality $(\mathrm{Li}, 2016)$. In CFA, absolute fit indices are analysed such as the Chi-Squared $\left(\chi^{2}\right)$, normed Chi-Squared $\left(\chi^{2} / d f\right)$ and the Standardized Mean Square Residual (SRMR); also, relative fit indices such as the Comparative Fit Index (CFI) and Tucker-Lewis Index (TLI); finally, non-centrality based index such as the Mean Square Error of Approximation (RMSEA). A factor model is considered to have an adequate fit when the $\chi^{2}$ is not significant $(p>.05)$, the $\chi^{2} / d f$ is less than 4, SRMR and RMSEA are less than .08 and CFI and TLI are higher than .90 (Byrne, 2008; Brown, 2015; Jonason et al., 2020; Yang-Wallentin et al., 2010). Factor loadings $(\lambda)$ of the model with the best fit were also analysed to verify that the saturation of the items in each factor contributes significantly to the analysed model and that its explained variance is more consolidated. Saturations equal to or greater than .5 are considered adequate (Dominguez-Lara, 2018).

In addition, the presence of high intercorrelations between factors and good fit indices, suggests that the relationship in the dimensions can be explained by the presence of a general factor (GF), which explains a greater variance of the items with respect to specific factors (SF) (Dominguez-Lara \& Rodriguez, 2017), therefore, the existence of a GF can be hypothesized. In order to analyse this, specific indices such as the Omega hierarchical for the general factor $\left(\omega_{\mathrm{H}}\right)$ and the specific factors $\left(\omega_{\mathrm{Hs}}\right)$, Explained Common Variance (ECV), and the Percent of Uncontaminated Correlations (PUC) are used. It is accepted that a bifactor model presents a good fit 
Moreta-Herrera, R., Dominguez-Lara, S., Vaca-Quintana, D., Zambrano-Estrella, J., Gavilanes-Gómez, D., Ruperti-Lucero, E., Bonilla, D.: Validation and Reliability of GHQ-28 in Ecuador

when $\omega_{\mathrm{H}}$ is > .70; ECV > .60 and PUC > .70 (Reise et al., 2013; Rodriguez et al., 2016; Smits et al., 2015).

After that, reliability was analysed through the Omega coefficient $(\omega$, McDonald, 1999; Ventura-León \& Caycho-Rodríguez, 2017), with a 95\% confidence interval (95\% CI, Padilla \& Divers, 2013). On the other hand, convergence validity was analysed using the MHC-SF, to identify the approximation that the GHQ has with the construct "general health" through the Pearson coefficient $(r)$; and discriminant validity comparing participants identified as part of a "risk group" by means of the MHC-SF versus patients identified as being in the "non-risk group", using the Student's $t$-test for independent samples.

Statistical treatment of the results was carried out using the $\mathrm{R}$ software in its version 4.0 (R Core Team, 2019) with the MNV, Lavaan, and MBESS packages; and the IndicesBifactor.xls module for the bifactor fit indices (Dominguez-Lara \& Rodriguez, 2017).

\section{Results}

\section{Preliminary Analysis}

Table 1 shows the results of the means obtained in each of the 28 items. It is also evident that the mean scores are homogeneous between items and that it fluctuates between $M=0.13$ for items $22,23,24,25$, and 26; and $M=0.30$ for items 2 and 3.

On the other hand, it can be seen that items 12, 15, 17, 19, 20, 21, 22, 23, 24, $25,26,27$, and 28 exceed the critical number of \pm 2 in the values of $g 1$ or $g 2$, this suggests that there is no univariate normality among scores. Regarding multivariate normality between the items, Mardia tests for skewness and kurtosis report significance $(p<.05)$, therefore this assumption is not fulfilled.

\section{Table 1}

Preliminary Analysis of the GHQ-28 Items

\begin{tabular}{lcccc}
\hline Items & $\boldsymbol{M}$ & $\boldsymbol{S D}$ & $\boldsymbol{g}_{\boldsymbol{1}}$ & $\boldsymbol{g}_{\mathbf{2}}$ \\
\hline Item 01 & 0.24 & 0.43 & 1.23 & -0.48 \\
Item 02 & 0.30 & 0.46 & 0.86 & -1.27 \\
Item 03 & 0.30 & 0.46 & 0.88 & -1.23 \\
Item 04 & 0.24 & 0.43 & 1.21 & -0.55 \\
Item 05 & 0.25 & 0.43 & 1.14 & -0.70 \\
Item 06 & 0.27 & 0.45 & 1.02 & -0.96 \\
Item 07 & 0.26 & 0.44 & 1.12 & -0.75 \\
Item 08 & 0.23 & 0.42 & 1.29 & -0.35 \\
Item 09 & 0.23 & 0.42 & 1.26 & -0.42
\end{tabular}




\begin{tabular}{lcccc}
\hline Items & $\boldsymbol{M}$ & $\boldsymbol{S D}$ & $\boldsymbol{g}_{\boldsymbol{I}}$ & $\boldsymbol{g}_{\mathbf{2}}$ \\
\hline Item 10 & 0.27 & 0.45 & 1.01 & -0.98 \\
Item 11 & 0.25 & 0.43 & 1.14 & -0.70 \\
Item 12 & 0.20 & 0.40 & 1.54 & 0.36 \\
Item 13 & 0.26 & 0.44 & 1.11 & -0.78 \\
Item 14 & 0.21 & 0.40 & 1.46 & 0.13 \\
Item 15 & 0.20 & 0.40 & 1.52 & 0.31 \\
Item 16 & 0.21 & 0.41 & 1.41 & 0.00 \\
Item 17 & 0.18 & 0.39 & 1.64 & 0.68 \\
Item 18 & 0.20 & 0.40 & 1.50 & 0.26 \\
Item 19 & 0.19 & 0.39 & 1.60 & 0.57 \\
Item 20 & 0.18 & 0.39 & 1.64 & 0.68 \\
Item 21 & 0.18 & 0.39 & 1.65 & 0.74 \\
Item 22 & 0.13 & 0.34 & 2.19 & 2.81 \\
Item 23 & 0.13 & 0.33 & 2.27 & 3.17 \\
Item 24 & 0.13 & 0.33 & 2.27 & 3.17 \\
Item 25 & 0.13 & 0.34 & 2.22 & 2.92 \\
Item 26 & 0.13 & 0.33 & 2.24 & 3.05 \\
Item 27 & 0.14 & 0.34 & 2.14 & 2.58 \\
Item 28 & 0.17 & 0.38 & 1.75 & 1.05 \\
\hline
\end{tabular}

Note. $M$ - Arithmetic mean; $S D$ - Standard Deviation; $g 1$ - Skewness; $g 2-$ Kurtosis. ${ }^{* * *} p<.001$.

\section{Confirmatory Factor Analysis}

Table 2 shows the results of the CFA of GHQ-28. Here four models were tested. The first corresponds to the model of four correlated factors of 28 items (Goldberg, 1978), the second model corresponds to the short version of 17 items (GHQ-17, Prady et al., 2013). High intercorrelations between factors in models 1 and 2 allow us to hypothesize the presence of a general factor (GF) that would better explain the behaviour of the items, so a third and fourth model of the two previous versions were tested as bifactor models: with a GF and four SF.

Within the analysis of the models, it is observed that the models with correlated factors with 17 and 28 items, as well as the bifactor model of 28 items present good fit indicators, except for $\chi^{2}$, which presented significance in models 1 and 2 . However, a better fit can be found in the 28 -item bifactor model. Absolute Fit Indices $\left(\chi^{2}, \chi^{2} / d f\right.$, and SRMR), Relative Fit Indices (CFI and TLI) and non-centrality-based index (RMSEA) of this model are within adequate parameters suggesting that this model is suitable for Ecuadorian college students. 
Moreta-Herrera, R., Dominguez-Lara, S., Vaca-Quintana, D., Zambrano-Estrella, J., Gavilanes-Gómez, D., Ruperti-Lucero, E., Bonilla, D.: Validation and Reliability of GHQ-28 in Ecuador

Table 2

Confirmatory Factor Analysis of GHQ-28

\begin{tabular}{lccccccc}
\hline Models & $\chi^{2}$ & $d f$ & $\chi^{2} d d f$ & CFI & TLI & SRMR & RMSEA \\
\hline 28 items - 4 factors & $694.95^{* * *}$ & 344 & 2.02 & .910 & .900 & .041 & $.045[.041-.050]$ \\
17 items - 4 factors & $261.99^{* * * *}$ & 113 & 2.31 & .940 & .920 & .034 & $.052[.044-.060]$ \\
28 items - Bifactor & 357.81 & 322 & 1.11 & .991 & .989 & .059 & $.015[.000-.023]$ \\
17 items - Bifactor & 90.99 & 102 & 0.90 & 1.00 & 1.01 & .048 & $.000[.000-.017]$ \\
\hline
\end{tabular}

Note. $\chi^{2}$ - Chi square; $d f$ - degrees of freedom; $\chi^{2} / d f$ - normed Chi square; CFI - Comparative Adjustment Index; TLI - Tucker-Lewis Index; SRMR - Standardized Mean Square Residue; RMSEA - Mean Square Error of Approximation. ${ }^{* * *} p<.001$.

In addition, Figure 1 shows factor loadings $(\lambda)$ of the items of both the GF that groups all the items, and the SF. In this regard, the GF presents better saturation of the items, which fluctuate between $\lambda_{4}=.869$ and $\lambda_{23}=.655$, and being above .50 , this allows a better explanation of the variance, thus contributing significantly to the model unlike the saturations of the SF. Likewise, in the specific fit indices for bifactor models, the values of $\omega_{\mathrm{H}}, \mathrm{EVC}$ and PUC are within the expected parameters, so a GF would better explain the general health model with 28 items.

\section{Reliability and Convergence Validity}

Given that the configuration of a general factor and four specifics factors that explain the items of the GHQ-28 is evident, its integral reliability is analyzed, which is equivalent to very high and therefore adequate for Ecuadorian college students. Convergence validity is also verified, as observed in Table 3, through the MSC-SF test. GF of the GHQ-28 and the four SF converge significantly $(p<.05)$ in a moderate and negative way with a similar test when measuring the construct "mental health". It is estimated that the GHQ-28 is a useful instrument for this population. 


\section{Figure 1}

\section{GHQ-28 Bifactor Model with One General Factor and Four Factors}

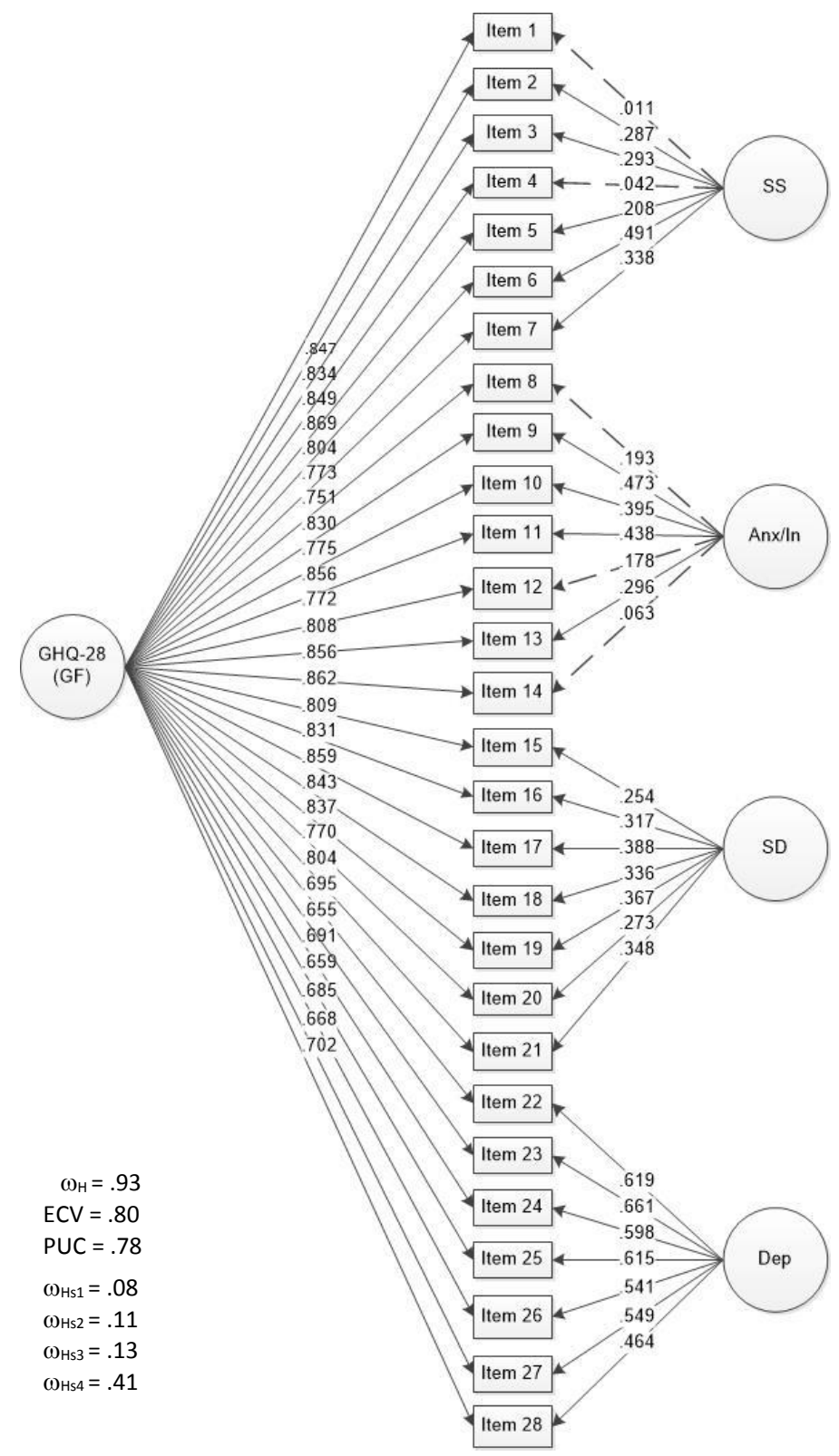

Note. The circles show the latent variables, while the rectangles show the observable variables along with the saturations. SS - Somatic symptoms; Anx/In - Anxiety and Insomnia; SD - Social Dysfunction; Dep - Depression; $\omega \mathrm{H}$ - Hierarchical Omega; ECV - Explained Common Variance; PUC - Percentage of uncontaminated correlations; $\omega \mathrm{Hs}$ - Hierarchical Specific Omega. 
Moreta-Herrera, R., Dominguez-Lara, S., Vaca-Quintana, D., Zambrano-Estrella, J., Gavilanes-Gómez, D., Ruperti-Lucero, E., Bonilla, D.:

Validation and Reliability of GHQ-28 in Ecuador

\section{Table 3}

Analysis of Validity of Convergence and Reliability of the GHQ-28

\begin{tabular}{|c|c|c|c|c|c|}
\hline Variables & Som & A-I & SD & Dep & GHQ-28 \\
\hline Emotional Well-being & $-.64^{* *}$ & $-.67^{* *}$ & $-.53^{* *}$ & $-50^{* *}$ & $-.64^{* *}$ \\
\hline Social Welfare & $-.62^{* *}$ & $-.64^{* *}$ & $-.49^{* *}$ & $-.45^{* *}$ & $-.61^{* *}$ \\
\hline $\begin{array}{l}\text { Psychological Well- } \\
\text { being }\end{array}$ & $-.64^{* * *}$ & $-.68^{* * *}$ & $-.49^{* * *}$ & $-.48^{* * *}$ & $-.63^{* *}$ \\
\hline Keyes Well-being Scale & $-.67^{* *}$ & $-.70^{* *}$ & $-.53^{* *}$ & $-.50^{* *}$ & $-.66^{* *}$ \\
\hline $\begin{array}{l}\text { Reliability ( } \omega ; \\
\text { IC }[95 \%])\end{array}$ & $\begin{array}{c}.949 \\
{[.939-.959]}\end{array}$ & $\begin{array}{c}.957 \\
{[.948-.966]}\end{array}$ & $\begin{array}{c}.962 \\
{[.952-.971]}\end{array}$ & $\begin{array}{c}.963 \\
{[.952-.975]}\end{array}$ & $\begin{array}{c}.981 \\
{[.978-.984]}\end{array}$ \\
\hline
\end{tabular}

Note. $\omega$-McDonald coefficient; CI - Confidence Intervals; Som - Somatization; A-I - Anxiety/ insomnia; SD - Social disfuntion; Dep - Depressión; GHQ-28 - General Health Questionnarie-28. ${ }^{* *} p<.01$.

\section{Discussion}

The goals of this study were to verify the internal structure of the GHQ-28, as well as the reliability and validity due to its association with other variables in a sample of Ecuadorian college students. Regarding the evidence of validity from the analysis of its internal structure, results suggest that the factorial model of four correlated dimensions of the GHQ-28 and GHQ-17 present an adequate adjustment in the sample of Ecuadorian college students based on absolute fit indices $\left(\chi^{2}, \chi^{2} / \mathrm{df}\right.$, and SRMR), relative fit indices (CFI and TLI) and non-centrality based index (RMSEA) (Byrne, 2008; Brown, 2015; Yang-Wallentin et al., 2010). Findings of this study are similar to preliminary studies carried out in Spain (Pérez et al., 2010), South Africa (de Kock et al., 2014) and Iran (Ghanbarnejad et al., 2013) for 28 items; and Prady et al. (2013) for 17 items. However, due to the high intercorrelations between factors founded, we tested an alternative model incorporating a GF that explains the 28 items together with four SF (bifactor model).

The bifactor model presents a better statistical fit than the oblique factor models of 28 and 17 items. Factor loadings $(\lambda)$ of the GF are adequate and allow a consistent explained variance of the model (Dominguez-Lara, 2018). Furthermore, fit indices for the bifactor models are within the acceptance parameters (Reise et al., 2013; Rodriguez et al., 2016; Smits et al., 2015). This finding is relevant and innovative because it provides a better factor structure for the GHQ-28 with robust estimators, evidencing that the use of a single score is recommended. Therefore, these results are ground-breaking in the field of psychometric analysis of this assessment tool and will allow better normalization processes of the population through evaluation.

In the case of the reliability of the scale, results show an optimal internal consistency of the item scores in the analysed sample and are consistent with similar studies worldwide (de Kock et al., 2014; Galindo et al., 2017; Ghanbarnejad et al., 
2013; Hjelle et al., 2019; Lobo et al., 1986; Pérez et al., 2010; Vallejo et al., 2014), and since we first verified the factor structure for the test, reliability analysis turns out to be more dependable to confirm the usefulness and precision of the scale for college students (Batista-Fogueta et al., 2004).

Regarding the validity evidence due to its relationship with other variables analysed with the help of the MCH-SF test (Contreras et al., 2017; Keyes, 2005), it is estimated that the GHQ-28 converges adequately with the MCH-SF with moderate correlations. These values can be corroborated with the study by Failde et al. (2000) who analyse this property with a similar assessment tool for the perception of health and also with the findings of Chen et al. (2010) who prove it with measures of anxiety and depression.

On the implications of the founded results, two aspects are deepened. First, it can be considered one of the most complete studies that exist in terms of the psychometric exploration of the GHQ-28. In addition, it provides statistical evidence about the behaviour of the test in terms of the factor structure in Ecuadorian college students and, as mentioned before, it has been barely analysed with SEM techniques and the proper estimators for ordinal variables and in the absence of multivariate normality.

In this way, these findings help fill gaps both in instrumental and methodological scientific literature applying multivariate statistics for scale validation, as well as their different statistical estimators. It should be noted that the excessive confidence placed in the GHQ-28 by researchers, has led to a neglect of the rigorous use of psychometric validation techniques that adequately analyse the internal structure of the test. Although the use of the four-factor model with 28 and 17 items has factorial validity that supports its use, a bifactor model of the test estimates a better factorial interpretation of the measure and a greater interpretation of the behaviour of the latent measures, which allow greater operability of the measure.

The second aspect is related to the practical implications of the use of this test to assess university populations in Ecuador. This will allow greater confidence in the assessment results obtained by the test and will provide support for diagnosis, showing good evidence of validity in terms of internal structure as well as convergence with a measure of well-being.

The conclusions of the study show that the GHQ-28 has a broader structural potential than previously reported. This bifactorial structure, different from the one reported in the original model, is more versatile and comprehensive for the understanding and evaluation of the mental health construct and, along with an adequate criterion of reliability and validity, will allow further development in the investigation and diagnosis of mental health, as well as its practical utility in the population of Ecuador. 
Moreta-Herrera, R., Dominguez-Lara, S., Vaca-Quintana, D., Zambrano-Estrella, J., Gavilanes-Gómez, D., Ruperti-Lucero, E., Bonilla, D.: Validation and Reliability of GHQ-28 in Ecuador

\section{Limitations and Future Research}

Like any instrumental study, this research presents some limitations that need to be considered for future studies. One of them has to do with the type of sample analysed that was exclusively Ecuadorian college students, therefore, to expand the universality of the measure, new confirmatory studies with other types of samples (adolescents, general population, adults) are required in the future. It is also important to compare the validity of the scale with other versions of the GHQ, such as the 12 or 60-item version, to know the behaviour of the measure in its different versions, and to see the degree of adjustment in the Ecuadorian population. In the same way, it is important to investigate the equivalence of measurement of the test among groups classified by sex, socio-demographic conditions, nationality, and others to strengthen comparative studies.

\section{References}

Ato, M., López, J., \& Benavente, A. (2013). Un sistema de clasificación de los diseños de investigación en psicología [A classification system for research designs in psychology]. Anales de Psicología, 29(3), 1038-1059. https://doi.org/10.6018/analesps.29.3.178511

Batista-Fogueta, Manuel, J., Coenders, G., \& Alonso, J. (2004). Análisis factorial confirmatorio. Su utilidad en la validación de cuestionarios relacionados con la salud [Confirmatory factor analysis. Its usefulness in the validation of health-related questionnaires]. Medicina Clínica, 122(Supl 1), 21-7.

Berlin, M., Modin, B., Gustafsson, P. A., Hjern, A., \& Bergström, M. (2012). The impact of school on children's and adolescents' mental health (2012-5-15). The Swedish National Board of Health and Welfare \& Center for Health Equity Studies (CHESS).

Brown, T. A. (2015). Confirmatory factor analysis for applied research (Vol. 2). Guilford Publications.

Byrne, B. M. (1998). Structural equation modeling with LISREL, PRELIS, and SIMPLIS: Basic Concepts, applications and programming. Lawrence Erlbaum Associates.

Chen, C., Zhang, H. J., Jiang, H., LI, W. J., \& Lü, L. (2010). Assessing the general mental health of college students: Psychometric properties of GHQ-28. Journal of Shandong University (Health Science), 48(3), 159-162.

Chen, F. F., Jing, Y., Hayes, A., \& Lee, J. M. (2013). Two concepts or two approaches? A bifactor analysis of psychological and subjective well-being. Journal of Happiness Studies, 14(3), 1033-1068. https://doi.org//10.1007/s10902-012-9367-X

Chen, F. F., West, S. G., \& Sousa, K. H. (2006). A comparison of bifactor and second-order models of bifactor and second-order models of quality of life. Multivariate Behavioral Research, 41, 189-225. 
Contreras, E. K., Pacheco, G., Sizer, M., Keyes, C., \& Medina, W. (2017). Fiabilidad y validez de la Escala del Contínuum de Salud Mental (MHC-SF) en el contexto ecuatoriano [Reliability and validity of the Mental Health Continuum Scale (MHC - SF) in the Ecuadorian context]. Ciencias Psicológicas, 11(2), 223-232. https://doi.org/10.22235/cp. v11i2.1499

Cornaglia, F., Crivellaro, E., \& McNally, S. (2015). Mental health and education decisions. Labour Economics, 33, 1-12. https://doi.org/10.1016/j.labeco.2015.01.005

de Kock, F. S., Görgens-Ekermans, G., \& Dhladhla, T. J. (2014). A confirmatory factor analysis of the General Health Questionnaire-28 in a Black South African sample. Journal of Health Psychology, 19(10), 1222-1231. https://doi.org/10.1177/ 135910531348897

Dominguez-Lara, S. (2018). Propuesta de puntos de corte para cargas factoriales: Una perspectiva de fiabilidad de constructo [Proposal of cut-off points for factorial loads: A construct reliability perspective]. Enfermería Clínica, 28(6), 401-402. https://doi.org/10.1016/j.enfcli.2018.06.002

Dominguez-Lara, S., \& Rodriguez, A. (2017). Índices estadísde modelos bifactor [Statistical indices of bifactor models]. Interacciones, 3(2), 59-65. https://doi.org/10.24016/2017. $\mathrm{v} 3 \mathrm{n} 2.51$

Dunn, T. J., Baguley, T., \& Brunsden, V. (2014). From alpha to omega: A practical solution to the pervasive problem of internal consistency estimation. British Journal of Psychology, 105, 399-412. https://doi.org/10.1111/bjop.12046

Echeverría, G., Torres, M., Pedrals, N., Padilla, O., Rigotti, A., \& Bitran, M. (2017). Validation of a Spanish version of the Mental Health Continuum-short form questionnaire. Psicothema, 29(1), 96-102.

Failde, I., Ramos, I., \& Fernandez-Palacin, F. (2000). Comparison between the GHQ-28 and SF-36 (MH 1-5) for the assessment of the mental health in patients with ischaemic heart disease. European Journal of Epidemiology, 16(4), 311-316. https://doi.org/10.1023/ A: 1007688525023

Ferrando, P. J., \& Anguiano-Carrasco, C. (2010). El análisis factorial como técnica de investigación en psicología [Factor analysis as a research technique in psychology]. Papeles del Psicólogo, 31(1), 18-33.

Field, A. (2009). Discovering statistics using SPSS (3rd ed.). Sage.

Galindo, O., Meneses, A., Herrera, Á., Cabrera, P., Suchil, L., Rivera, L., \& Aguilar, J. (2017). Propiedades psicométricas del Cuestionario General de Salud de Goldberg -GHQ-28-en cuidadores primarios informales de pacientes con cáncer [Psychometric properties of the Goldberg General Health Questionnaire - GHQ-28- in informal primary caregivers of cancer patients]. Psicooncología, 14(1), 71-81. https://dx.doi.org/10.5209/PSIC. 55812

Garrido, E. C., \& Delgado, S. C. (2017). Phubbing. Conectados a la red y desconectados de la realidad. Un análisis en relación al bienestar psicológico [Phubbing. Connected to the network and disconnected from reality. An analysis in relation to psychological wellbeing]. Píxel-Bit. Revista de Medios y Educación, 50, 173-185. 
Moreta-Herrera, R., Dominguez-Lara, S., Vaca-Quintana, D., Zambrano-Estrella, J., Gavilanes-Gómez, D., Ruperti-Lucero, E., Bonilla, D.: Validation and Reliability of GHQ-28 in Ecuador

Ghanbarnejad, A., Turki, H., Golestan, B., Arbabi, M., \& Nedjat, S. (2013). Factor structure of Persian General Health Questionnaire-28 in dermatologic patients: A confirmatory factor analysis. International Electronic Journal of Medicine, 2(1), 11-21.

Gibbons, P., Flores de Arévalo, H., \& Mónico, M. (2004). Assessment of the factor structure and reliability of the 28 item version of the General Health Questionnaire (GHQ-28) in El Salvador. International Journal of Clinical and Health Psychology, 4(2), 389-398.

Goldberg, D. (1978). Manual del General Health Questionnaire. NFER Publishing.

Goldberg, D. P., \& Hillier, V. F. (1979). A scaled version of the General Health Questionnaire. Psychological Medicine, 9, 139-145.

Hjelle, E., Bragstad, L., Zucknick, M., Kirkevold, B., \& Sveeen, U. (2019). The General Health Questionnaire-28 (GHQ-28) as an outcome measurement in a randomized controlled trial in a Norwegian stroke population. BMC Psychology, 7(18), https://doi.org/10.1186/s40359-019-0293-0

Holzinger, K. \&. (1937). The bi-factor method. Psychometrika, 47, 41-54.

Hope, V., \& Henderson, M. (2014). Medical student depression, anxiety and distress outside North America: A systematic review. Medical Education in Review, 48(10), 963-979. https://doi.org/10.1111/medu.12512

Jonason, P. K., Żemojtel-Piotrowska, M., Piotrowski, J., Sedikides, C., Campbell, W. K., Gebauer, J. E., Maltby, J., Adamovic, M., Adams, B. G., Lestari Kadiyono A., Atitsogbe, K. A., Bundhoo, H. Y., Bălțătescu, S., Bilić, S., Gruneau Brulin, J., Chobthamkit, P., Del Carmen Dominguez, A., Dragova-Koleva, S., El-Astal, S., Esteves, C. S. ... Yahiiaev, I. (2020). Country- level correlates of the dark triad traits in 49 countries. Journal of Personality. https://doi.org/10.1111/jopy.12569

Karaś, D., Cieciuch, J., \& Keyes, C. L. (2014). The Polish adaptation of the Mental Health Continuum-short form (MHC-SF). Personality and Individual Differences, 69, 104 109.

Keyes, C. L. (2005). Mental illness and/or mental health? Investigating axioms of the complete state model of health. Journal of Consulting and Clinical Psychology, 73(3), 539-548. https://doi.org/10.1037/0022-006X.73.3.539

Khodarahimi, S., \& Fathi, R. (2016). Mental health, coping styles, and risk-taking behaviors in young adults. Journal of Forensic Psychology Practice, 16(4), 287-303. https://doi.org/10.1080/15228932.2016.1196101

Li, C. H. (2016). Confirmatory factor analysis with ordinal data: Comparing robust maximum likelihood and diagonally weighted least squares. Behavior Research Methods, 48(3), 936-949. https://doi.org/10.3758/s1342

Lipson, S., Gaddis, S., Heinze, J., Beck, K., \& Eisenberg, D. (2015). Variations in student mental health and treatment utilization across US colleges and universities. Journal of American College Health, 63(6), 388-396. https//doi.org/10.1080/07448481.2015.1040411

Lobo, A., Pérez-Echeverría, M. J., \& Artal, J. (1986). Validity of the scaled version of the General Health Questionnaire (GHQ-28) in a Spanish population. Psychological Medicine, 16(1), 135-140. https://doi.org/10.1017/S0033291700002579. 
Mardia, K. (1970). Measures of multivariate skewness and kurtosis with applications measures of multivariate skewness and kurtosis with applications. Biometrika, 57, 519530. https://doi.org/10.2307/2334770

Mayorga-Lascano, M., \& Moreta-Herrera, R. (2019). Síntomas clínicos, subclínicos y necesidades de atencion psicológica en estudiantes universitarios con bajo rendimiento [Psychological care needs for underperforming college students with clinical and subclinical symptoms]. Educación, 43(2), https://doi.org/10.15517/REVEDU.V43I2. 32239

McDonald, R. P. (1999). Test theory: A unified treatment. Lawrence Erlbaum Associates, Inc.

Moreta-Herrera, R., López-Calle, C., Ramos-Ramírez, M., \& López-Castro, J. (2018). Estructura factorial y fiabilidad del Cuestionario de Salud General de Goldberg (GHQ12) en universitarios ecuatorianos [Factor structure and reliability of the Goldberg General Health Questionnaire (GHQ-12) in Ecuadorian university students]. Revista Argentina de Ciencias del Comportamiento, 10(3), 35-42. https://doi.org/10.32348/ 1852.4206.v10.n3.20405

Moreta-Herrera, R., Perdomo-Pérez, M., Reyes-Valenzuela, C., Torres-Salazar, C., \& Ramírez-Iglesias, G. (2021). Invarianza factorial según nacionalidad y fiabilidad de la Escala de Afecto Positivo y Negativo (PANAS) en universitarios de Colombia y Ecuador [Factorial invariance according to nationality and reliability of the Positive and Negative Affect Scale (PANAS) in university students from Colombia and Ecuador.]. Anuario de Psicología, 51(2), 76-85. https://doi.org/10.1344/anpsic2021.51.9

Moreta-Herrera, R., Zambrano-Estrella, J., Sánchez-Vélez, H., \& Naranjo-Vaca, S. (2021). Salud mental en universitarios del Ecuador: Síntomas relevantes, diferencias por género y prevalencia de casos [Mental health in university students in Ecuador: Relevant symptoms, differences by gender and prevalence of cases]. Pensamiento Psicológico, 19(1), 1-26. https://doi.org/10.11144/Javerianacali.PPSI19.smue.

Padilla, M. A., \& Divers, J. (2013). Coefficient omega bootstrap confidence intervals: Nonnormal distributions. Educational and Psychological Measurement, 73(6), 956972. https://doi.org/10.1177/0013164413492765

Pérez, P., Lozano, O., \& Rojas, A. (2010). Propiedades psicométricas del GHQ-28 en pacientes con dependencia a opiáceos [Psychometric properties of GHQ-28 in patients with opiate dependence]. Adicciones, 22(1), 65-72. https://doi.org/10.20882/adicciones.216

Prady, S. L., Miles, J. N., Pickett, K. E., Fairley, L., Bloor, K., Gilbody, S., Kiernan, K., Mann, R., \& Wright, J. (2013). The psychometric properties of the subscales of the GHQ-28 in a multi-ethnic maternal sample: Results from the Born in Bradford cohort. BMC Psychiatry, 13(1), 55. https://doi.org/10.1186/1471-244X-13-55

Prince, M., Patel, V., Saxena, S., Maj, M., Maselko, J., Phillips, M. R., \& Rahman, A. (2007). No health without mental health. The Lancet, 370(9590), 859-877. https://doi.org/10.1016/S0140-6736(07)61238-0

R Core Team. (2019). R: A language and environment for statistical computing. R Foundation for Statistical Computing. 
Moreta-Herrera, R., Dominguez-Lara, S., Vaca-Quintana, D., Zambrano-Estrella, J., Gavilanes-Gómez, D., Ruperti-Lucero, E., Bonilla, D.: Validation and Reliability of GHQ-28 in Ecuador

Reise, S., Scheines, R., Widaman, K., \& Haviland, M. (2013). Multidimensionality and structural coefficient bias in structural equation modeling: A bifactor perspective. Educational and Psychological Measurement, 73(1), 5-26. https://doi.org10.1177/ 00223891.2015.1089249

Rodriguez, A., Reise, S., \& Haviland, M. (2016). Evaluating bifactor models: Calculating and interpreting statistical indices. Psychological Methods, 21(2), 137-150. https://doi.org/ $10.1037 /$ met0000045

Saleh, D., Camart, N., \& Romo, L. (2017). Predictors of stress in college students. Frontiers in Psychology, 8, 1-19. https://doi.org/10.3389/fpsyg.2017.00019

Smits, I., Timmerman, M., Barelds, D., \& Meijer, R. (2015). The Dutch symptom checklist90-revised: Is the use of the subscales justified? European Journal of Psychological Assessment, 31(4), 263-271. https://doi.org/10.1027/1015-5759/a000233

Sterling, M. (2011). General Health Questionnaire-28 (GHQ-28). Journal of Physiotherapy, 57(4), 259.

Torres-Salazar, C., Moreta-Herrera, R., Ramos-Ramírez, M., \& López-Castro, J. (2020). Sesgos cognitivo de optimismo y percepción de bienestar en una muestra de universitarios ecuatorianos [Cognitive biases of optimism and perception of well-being in a sample of Ecuadorian university students.]. Revista Colombiana de Psicología, 29(1), 61-72. https://doi.org/10.15446/rcp.v29n1.75853

Tran, A., Tran, L., Geghre, N., Darmon, D., Rampal, M., Brandone, D., Gozzo, J.-M., Haas, H., Rebouillat-Savy, K., Caci, H., \& Avillach, P. (2017). Health assessment of French university students and risk factors associated with mental health disorders. PLOS ONE, 12(11), https://doi.org/10.1371/journal.pone.0188187

Vallejo, M. A., Rivera, J., Esteve-Vives, J., \& Rodríguez-Muñoz, M. (2014). El cuestionario general de salud (GHQ-28) en pacientes con fibromialgia: Propiedades psicométricas y adecuación [The general health questionnaire (GHQ-28) in patients with fibromyalgia: Psychometric properties and adequacy]. Clínica y Salud, 25(2), 105-110. https://dx.doi.org/10.1016/j.clysa.2014.06.005

Ventura-León, J., \& Caycho-Rodríguez, T. (2017). El coeficiente Omega: Un método alternativo para la estimación de la confiabilidad [The Omega coefficient: An alternative method for estimating reliability]. Revista Latinoamericana de Ciencias Sociales, Niñez y Juventud, 15(1), 625-627.

Vera-Villarroel, P., Celis-Atenas, K., Urzúa, A. S., Contreras, D., \& Lillo, S. (2016). Los afectos como mediadores de la relación optimismo y bienestar [Affects as mediators of the optimism and well-being relationship]. Revista Argentina de Clínica Psicológica, 25(2), 195-202.

Vergara-Moragues, E., \& González-Saiz, F. (2020). Predictive outcome validity of General Health Questionnaire (GHQ-28) in substance abuse patients treated in therapeutic communities. Journal of Dual Diagnosis, 16, 218-227. https://doi.org/10.1080/ 15504263.2019.1674465

Walsh, R. (2011). Lifestyle and mental health. American Psychologist, 66(7), 579-592. https://doi.org/10.1037/a0021769 
World Health Organization [WHO]. (1946). Constitution of the World Health Organization. International Health Conference (pp. 1-18). World Health Organization.

World Health Organization [WHO]. (2001). Fortaleciendo la prevención de salud mental [Strengthening mental health prevention]. World Health Organization.

World Health Organization [WHO]. (2014). Invertir en salud mental [Invest in mental health]. World Health Organization.

Yang-Wallentin, F., Jöreskog, K. G., \& Luo, H. (2010). Confirmatory factor analysis of ordinal variables with misspecified models. Structural Equation Modeling, 17(3), 392423. https://doi.org/10.1080/10705511.2010.489003

Zapata, M. A., \& Giraldo, L. F. (2012). Tratamiento de sustitución con Metadona para la adicción a la Heroína: Evaluación de un programa en Colombia [Methadone substitution treatment for heroin addiction: Evaluation of a program in Colombia]. Adicciones, 24(1), 69-76. https://doi.org/10.20882/adicciones.119

Żemojtel-Piotrowska, M., Piotrowski, J. P., Osin, E. N., Cieciuch, J., Adams, B. G., Ardi, R., Bălţătescu, S., Bogomaz, S., Lal Bhomi, A., Clinton, A., de Clunie, G. T., Czarna, A. Z., Esteves, C., Gouveia, V., Halik, M. H. J., Hosseini, A., Khachatryan, N., Vasant Kamble, S., Kawula, A., Miu-Chi Lun, V. ... \& Maltby, J. (2018). The Mental Health Continuum - short form: The structure and application for cross-cultural studies - A 38 nation study. Journal of Clinical Psychology, 74(6), 1034-1052. https://doi.org/10.1002/jclp.22570

\title{
Psihometrijska svojstva Upitnika općega zdravlja (GHQ-28) kod ekvadorskih studenata
}

\begin{abstract}
Sažetak
Cilj je rada bio analiza unutarnje strukture verzije Upitnika općega zdravlja od 28 čestica (GHQ28), kao i njegove pouzdanosti i valjanosti na uzorku ekvadorskih studenata. Primijenjena je konfirmatorna faktorska analiza, uz korištenje algoritma WLSMV (engl. weighted least square mean and variance adjusted), a izračunane su pouzdanost te konvergentna i diskriminacijska valjanost. Uzorak se sastojao od 495 studenata (56.6 \% žena), starosti između 18 i 35 godina $(M=$ 24.1 godina; $S D=2.1)$, polaznika triju sveučilišta u Ekvadoru (59.6\% državnih). Prema dobivenim rezultatima bifaktorski model upitnika GHQ-28 pokazuje najbolje indekse pristajanja; $\chi^{2}=357.81$; $p>0.05 ; d f=322 ; \chi^{2} / d f=1.11 ; \mathrm{CFI}=.991 ; \mathrm{TLI}=.989 ; \mathrm{SRMR}=0,059 ; \mathrm{RMSEA}=.015[.000-$ $.023] ; \omega_{\mathrm{H}}=.93 ; \mathrm{ECV}=0.90 ;$ PUC $=.78$. Upitnik GHQ-28 pouzdana je mjera koja u smislu konvergentne valjanosti značajno i negativno korelira $\mathrm{s}$ mentalnim zdravljem, procijenjenim pomoću upitnika MHC-SF, te uspješno diskriminira rizične i nerizične slučajeve. Na temelju svega navedenoga zaključuje se da bifaktorski model GHQ-28 najbolje pristaje podacima dobivenima na uzorku ekvadorskih studenata.
\end{abstract}

Ključne riječi: bifaktorski model, faktorska analiza, mentalno zdravlje, pouzdanost, valjanost

Primljeno: 17. 4. 2021. 